\title{
ANALISIS PEMODELAN STABILITAS DINDING PENAHAN TANAH PADA PROYEK FLYOVER ANTAPANI, KOTA BANDUNG
}

\author{
Pranata Kusumah $^{1}$, Chandra Afriade Siregar ${ }^{2}$, Hendra Garnida ${ }^{3}$ \\ 1,2,3 Universitas Sangga Buana YPKP \\ ${ }^{2}$ konrespodensi : chandra.afriade@usbypkp.ac.id
}

\begin{abstract}
Flyover construction provides benefits in areas that have heavy traffic movements. Flyover construction is also supported by a safe construction where in modeling a building will experience a decrease. There are various solutions that can be done so that a structure can be built on soft soil. One solution is to design or model the construction of retaining walls with stability that meets the requirements of the safety factor. Stability analysis on retaining walls with embankments will minimize deformation or very large settlements that can occur in a building. The modeling design is carried out using manual calculations and using Plaxis Professional 2D software version 8.6 based on the finite element method. This case study was conducted on the Antapani Flyover project (Bandung City, West Java). The design of retaining walls must take into account the stability against shear with a factor of safety $(F K)>1.5$, stability against overturning with a factor of safety $(F K)>2$ and stability against the bearing capacity of the soil with a factor of safety $(F K)>3$. And settlement when given the load on the building does not exceed the predetermined safety factor. Finally, it can be concluded that the design of the retaining wall in the Antapani Flyover project is safe against traffic movements and settlements that occur.
\end{abstract}

Keywords : Retaining Wall, Embankment, Subsidence, Safety Factor, Finite Element Method

\begin{abstract}
ABSTRAK
Pembangunan Flyover memberikan manfaat pada wilayah yang memiliki pergerakan lalu lintas yang padat. Pembangunan Flyover didukung juga dengan suatu kontruksi yang aman dimana didalam pemodelan suatu kontruksi akan mengalami suatu penurunan. Ada berbagai solusi yang dapat dilakukan agar suatu struktur dapat dibangun di atas tanah lunak. Salah satu solusi itu adalah dengan merancang atau memodelkan kontruksi dinding penahan tanah dengan stabilitas yang memenuhi syarat faktor keamanan. Analisis stabilitas pada dinding penahan tanah dengan timbunan akan meminimalisir deformasi atau penurunan yang sangat besar yang dapat terjadi pada suatu kontruksi, Desain pemodelan dilakukan dengan menggunakan perhitugan manual dan menggunakan perangkat lunak Plaxis Professional 2D versi 8.6 berdasarkan metode elemen hingga. Studi kasus ini dilakukan pada proyek Flyover Antapani (Kota Bandung, Jawa Barat). Perancangan dinding penahan tanah harus memperhitungkan stabilitas terhadap geser dengan faktor keamanan $(F K)>1,5$, stabilitas terhadap guling dengan faktor kemanan $(F K)>2$ dan stabilitas terhadap daya dukung tanah dengan faktor keamanan $(F K)>3$. Dan penurunan ketika diberi pembebanan di atas bangunan tidak melebihi faktor aman yang sudah ditentukan, Akhirnya dapat disimpulkan bahwa perancangan dinding penahan tanah pada proyek Flyover Antapani aman terhadap pergerakan lalu lintas dan penurunan yang terjadi.
\end{abstract}

Kata Kunci : Dinding Penahan Tanah, Timbunan, Penurunan, Faktor Keamanan, Metode Elemen Hingga.

\section{PENDAHULUAN}

\section{Latar Belakang}

Pembangunan suatu kontruksi jalan layang (Flyover) bertujuan untuk mengurai kemacetan atau pergerakan yang padat pada jalan, dengan merubah persimpangan sebidang menjadi persimpangan tidak sebidang. Pelaksanaan pembangunan kontruksi jalan layang (Flyover) sering kali terkendala dengan lahan yang terbatas dan penurunan tanah pada kontruksi Flyover. 
Tanah merupakan aspek yang sangat penting dalam suatu perencanaan bangunan infrastruktur. Karena pada dasarnya tidak ada suatu bangunan infrastruktur yang tidak dibangun diatas tanah. Dari pemeriksaan tanah dapat diketahui data-data tanah yang digunakan dalam perencanaan bangunan, Terutama dalam mendesain fondasi,timbunan dan dinding penahan tanah pada suatu struktur bangunan yang akan direncanakan.

Permasalahan penyeimbang ataupun stabilitas didetetapkan oleh keadaan beban tanah serta struktur di atasnya, Sebaliknya permasalahan deformasi membutuhkan perhitungan yang teliti buat mengenali besar distribusi tegangan yang ditimbulkan oleh beban struktur terhadap tanah serta berapa besar energi dukung tanah bawah yang bisa menahan struktur di atasnya ataupun gimana pengaruh besar timbunan terhadap penyusutan, longsor serta deformasi kepala jembatan.

\section{TINAJAUAN PUSTAKA}

\section{Tanah}

Tanah merupakan suatu dasar yang bertumpuan pada suatu struktur atau kontruksi pada suatu bangunan teknik sipil, baik kontruksi gedung, kontruksi jalan, kontruksi jembatan, kontruksi bendungan maupun kontruksi lainnya [1].

\section{Mortar}

Mortar merupakan campuran semen dan mortar yang digunakan untuk mengikat blok dengan mengisi ruang atau pori- pori tersebut. bahan yang digunakan

\section{Foam Agent}

Foam agent merupakan bahan yang mengandung zat- zat kimia sintetik yang berbasis protein (surfaktan) yang dapat menghasilkan busa yang digunakan untuk memproduksi beton.

\section{Timbunan}

Tanah timbunan adalah material tanah yang berfungsi untuk menyetarakan atau levelling suatu elevasi pada tanah atau kontruksi tanah. Tanah timbunan dibagi menjadi 2 (dua) jenis yaitu timbunan biasa (common fill) dan timbunan pilihan (selected fill) [1].

\section{Fondasi}

Fondasi merupakan kontruksi suatu bangunan yang berfungsi untuk menahan beban bangunan dari tanah dasar suatu kontruksi bangunan sehingga bangunan kuat menahan beban kontruksi di atasnya, maka dari itu fondasi harus memperhitungkan kestabilannya sehingga aman jika diberi gaya beban dari arah manapun [2].

\section{Tipe Keruntuhan}

Tipe keruntuhan pada suatu kontruksi bangunan khususnya pada infrastruktur fondasi pada bangunan pasti akan dihadapi dan akan menjadi masalah pada perencanaan suatu fondasi pada bangunan, maka dari itu untuk meminimalisir terjadinya keruntuhan pada suatu bangunan maka harus 
memperhitungkan beban gaya dengan stabilitas pada perencanaan fondasi dimana sebagai dasar untuk menahan beban dan gaya yang bekerja pada bangunan infrastruktur tersebut.

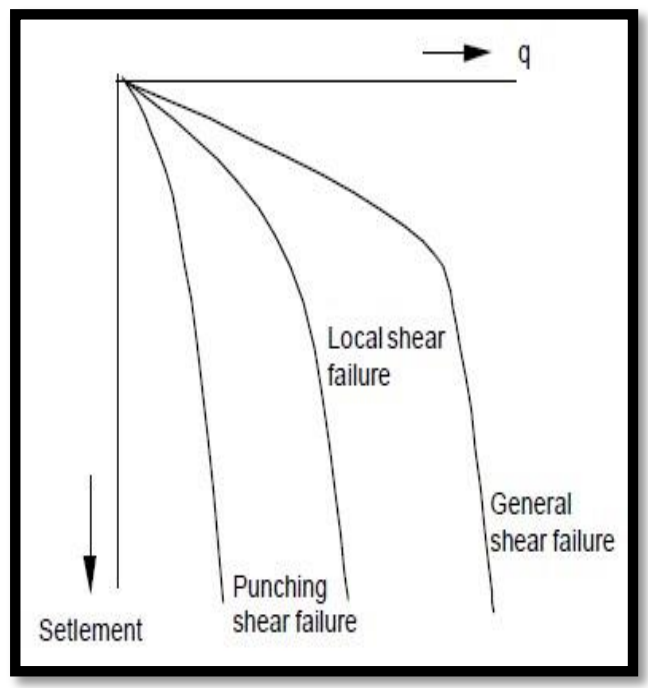

Gambar 1: Tipe Keruntuhan

\section{Dinding Penahan Tanah (DPT)}

Bilik penahan tanah merupakan sesuatu bangunan yang berperan buat memantapkan keadaan tanah tertentu pada biasanya dipasang pada wilayah tebing yang labil. Tipe konstruksi antara lain pendamping batu dengan mortar, pendamping batu dengan mortar, pendamping batu kosong, beton, kayu serta sebagainya. Bilik penahan tanah ialah sesuatu struktur yang direncanakan serta dibentuk buat menahan tekanan tanah lateral yang ditimbulkan oleh tanah urug ataupun tanah asli yang labil, sehingga bilik penahan tanah wajib nyaman terhadap perpindahan, penggulingan serta keruntuhan kapasitas dukung tanah.
Jenis-Jenis Dinding Penahan Tanah

\section{Dinding Penahan Gravitasi}

Dinding penahan yang dibuat dari beton tanpa adanya tulangan atau fondasi pasangan batu kali dimana kontruksinya hanya mengandalkan berat sendiri, dinding penahan tersebut seperti pada Gambar 2 (a). Biasanya tinggi dinding penahan tanah ini tingginya tidak lebih dari 4 meter.

\section{Dinding Penahan Kantiliver}

Dinding penahan kantiliver terbuat dari beton bertulang yang terdiri dari batang tipis dan lempeng dasar seperti pada Gambar 2 (c). Jenis dinding ini ekonois untuk digunakan untuk ketinggian 8 meter. 


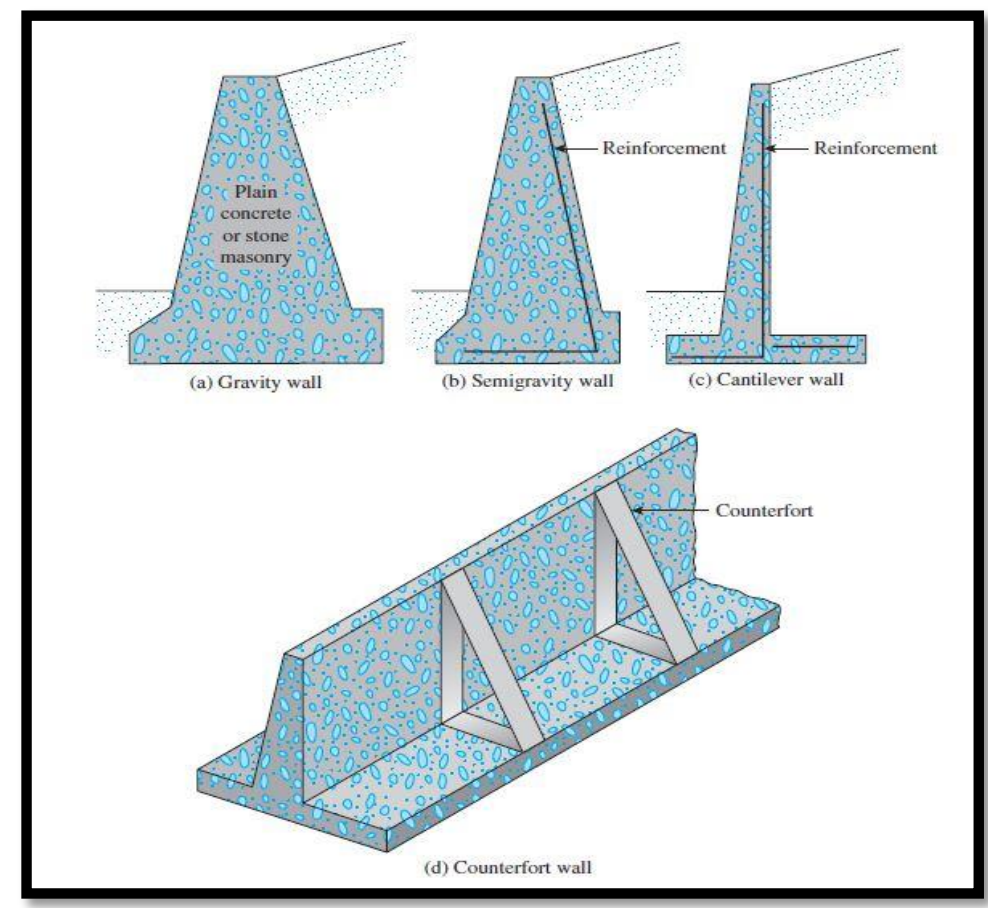

Gambar 2: Jenis-Jenis Dinding Penahan Tanah

\section{Dimensi Dinding Penahan Tanah}

Dalam merencanakan sebuah dinding penahan tanah maka langkah awal yang harus dilakukan adalah mengasumsi dimensi dari dinding penahan tanah sesuai dengan tipe yang diinginkan dan kemudian dilakukan stabilitasnya.

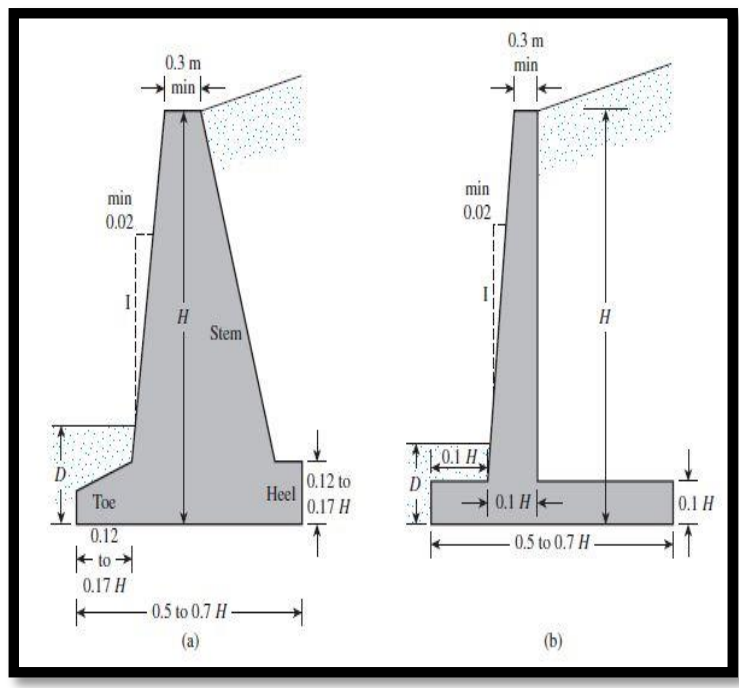

Gambar 3: Dimensi Dinding Penahan Tanah

\section{Stabilitas Dinding Penahan Tanah}

Bilik penahan yang di idamkan wajib normal terhadap guling, geser serta energi dukung tanah (tercantum penyusutan).

\section{Stabilitas Terhadap Guling}

Tekanan tanah lateral yang disebabkan oleh tanah urugan dibelakang bilik penahan, cenderung menggulingkan bilik dengan pusat rotasi pada ujung kaki depan fondasi semacam 
yang diarahkan pada Gambar 4. Momen penggulingan ini dilawan oleh momen akibat beban sendiri bilik penahan tanah serta momen akibat berat tanah diatas plat fondasi.

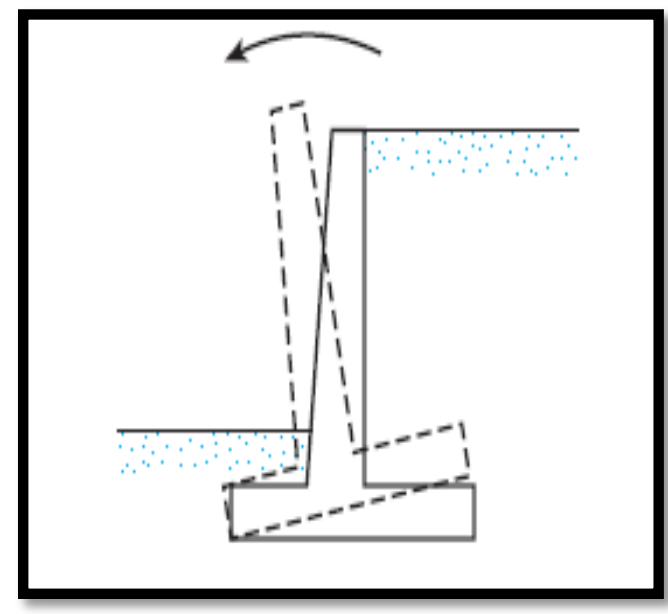

Gambar 4: Keruntuhan DPTTerhadap guling

Faktor aman terhadap penggulingan bergantung pada jenis tanah, yaitu :

- $\quad F_{g l} \geq 1,5$ untuk tanah dasar granular

- $\quad F_{g l} \geq 2$ untuk tanah dasar kohesif

\section{Stabilitas Terhadap Geser}

Stabilitas terhadap geser ialah perbandingan gaya- gaya yang menahan serta mendesak bilik penahan tanah. gaya yang menahan bahaya geser merupakan gesekan antara tanah dengan bawah pondasi dan tekanan tanah pasif di depan bilik penahan tanah akibat tanah timbunan.

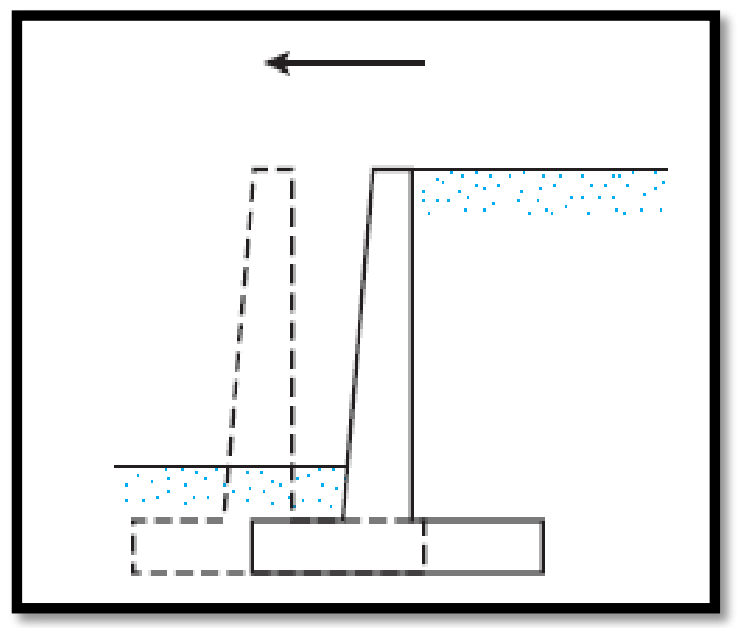

Gambar 5: Keruntuhan DPT Terhadap Geser

Faktor aman terhadap penggeseran $\left(F_{g s}\right)$ dasar fondasi minimum diambil 1,5. granular

- $F_{g s} \geq 2$ untuk tanah dasar kohesif

- $\quad F_{g s} \geq 1,5$ untuk tanah dasar 


\section{Stabilitas Terhadap Daya Dukung}

\section{Tanah}

Persamaan kapasitas energi dukung buat menghitung stabilitas dinding penahan tanah antara lain merupakan memakai kapasitas dukung Terzaghi, Mayerhoft serta Hansen. Aspek nyaman terhadap keruntuhan kapasitas dukung didefinisikan:

$F=\frac{q_{u}}{q} \geq 3$

Dengan q merupakan tekanan akibat struktur. Biasanya, aspek nyaman (F) terhadap keruntuhan tanah bawah minimum diambil sama dengan 3. Apabila dihitung dengan bersumber pada lebar fondasi efisien, ialah tekanan tanah fondasi ketanah bawah dibagi rata secara sama [3].

\section{Tekanan Tanah Lateral}

Tekanan tanah lateral merupakan suatu parameter perencanaan yang berarti di dalam metode pondasi serta bilik penahan. Tekanan tanah lateral ditimbulkan oleh dorongan tanah dibelakang struktur bilik penahan [3].

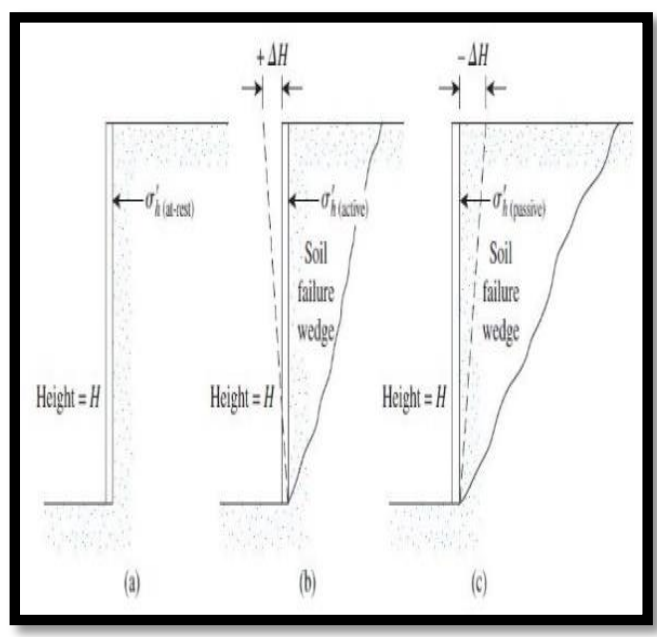

Gambar 6: Tekanan Tanah Lateral

\section{Tekanan Tanah Saat Diam}

Ditinjau pada sesuatu bilik penahan tanah dengan permukaan tanah mendatar pada Gambar 7. Mula- mula bilik serta tanah urug di belakangnya pada keadaan diam, sehingga tanah pada peran ini masih dalam keadaan elastis.

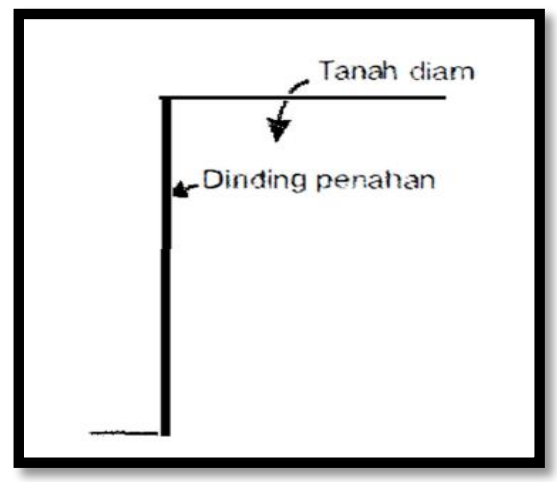

Gambar 7: Tekanan Tanah Diam 


\section{Tekanan Tanah Aktif}

Tekanan tanah aktif (active earth pressure) merupakan tekanan tanah lateral minimum yang menyebabkan kerutntuhan geser tanah akibat gerakan bilik menjahui tanah dibelakangnya, Pada sesuatu dikala gerakan bilik berikutnya menyebabkan terbentuknya keruntuhan geser tanah serta tekanan tanah pada bilik jadi konstan pada tekanan minimumnya.

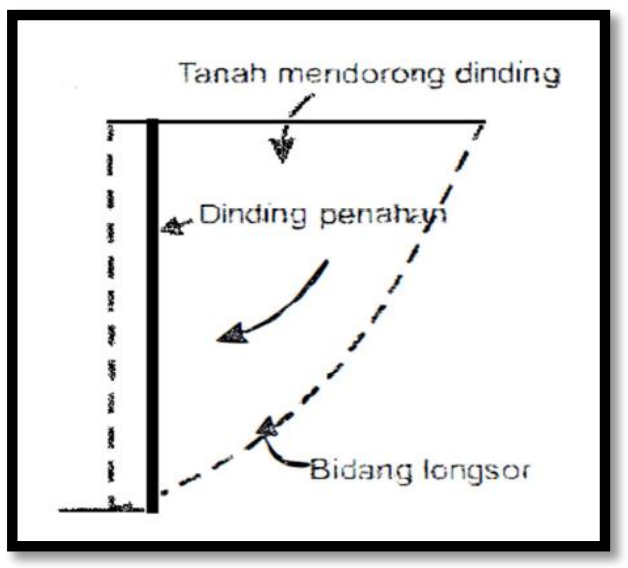

\section{Gambar 8: Tekanan Tanah Aktif}

\section{Tekanan Tanah Pasif}

Tekanan tanah pasif (passive earth pressure) merupakan tekanan tanah yang terjalin dikala gaya mendesak bilik penahan tanah kearah tanah urugannya, sebaliknya nilai banding tekanan arah horizontal serta arah vertical yang terjalin didefinisikan selaku koefisien tekanan tanah pasif ataupun kp serta tekanan tanah lateral maksimum yang menyebabkan keruntuhan geser tanah akibat gerakan bilik memencet tanah urug [5].

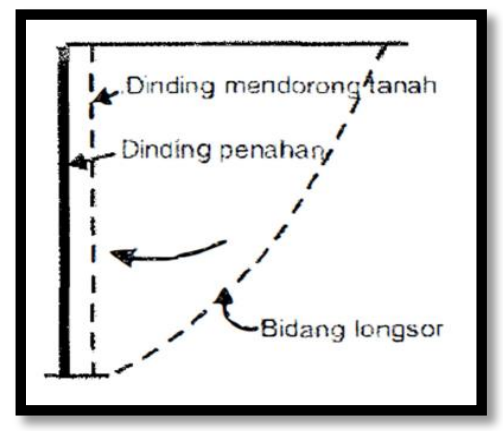

Gambar 9: Tekanan Tanah Pasif

\section{Penurunan}

Penurunan terjadi pada kontruksi bangunan akibat fondasi dari arah beban yang bekerja lebih besar dari perencanaan fondasi salah satunya penurunan konsolidasi pada tanah lunak [4].

\section{Beban Lalu Lintas}

Beban kemudian lintas ditambahkan kala melaksanakan perhitungan stabilitas. Pengelompokkan kelas jalur mengacu pada sistem klasifikasi jalur di Indonesia. Klasifikasi perencanaan jalur kelas I s. d IV pada Tabel 2. 6 didetetapkan bersumber pada 
besar volume Kemudian Lintas Setiap hari

Rata- Rata (LHR) serta guna jalannya [6].

Tabel 1 : Beban Lalu Lintas

\begin{tabular}{|c|c|}
\hline Kelas Jalan & Beban Kendaraan (kPa) \\
\hline I & 15 \\
\hline II & 12 \\
\hline III & 12 (asumsikan sama dengan jalan kelas III) \\
\hline IV & \\
\hline
\end{tabular}

\section{Plaxis 2D (Berbasis Elemen Hingga)}

Program Plaxis ialah sesuatu program yang terbuat bersumber pada perhitungan tata cara elemen sampai yang digunakan buat menganalisis deformasi serta stabilitas struktur geoteknik. Plaxis memiliki banyak keahlian menganalisa, semacam kestabilan kontruksi, aspek keamanan, deformasi, analisis kontruksi yang digunakan dalam aplikasi kontruksi timbunan, bilik penahan tanah serta terowongan. Oleh sebab itu, penulis memilah program Plaxis buat menganalisis kestabilan lereng yang terjalin pada posisi kajian.

Dengan terdapatnya program PLAXIS yang bisa menganalisis bermacam wujud geometris, mempermudah buat menghitung finite element dengan sangat kilat. Tampilan berbentuk grafis membuat pengguna lebih sering di dengar dalam melaksanakan perhitungan. Inputyang disediakan dalam program PLAXIS meliputi seluruh yang diperlukan dalam perhitungan manual, semacam: ukuran, material (material model, material type, general properties, permeability, $\quad$ stiffness). Dalam mengkalkulasikan sesuatu model, PLAXIS buatnya secara grafik sehingga mempermudah para pengguna buat melaksanakan perhitungan secara bertahap serta output yang menarik sehingga dengan mudah langsung diaplikasikan buat sesuatu presentasi.

\section{METODOLOGI PENELITIAN}

\section{Bagan Alir Penelitian}

Buat membagikan cerminan yang lebih jelas tentang tahapan penerapan riset dalam tugas akhir ini, hingga terbuat bagan alir riset semacam nampak pada Gambar 10. 


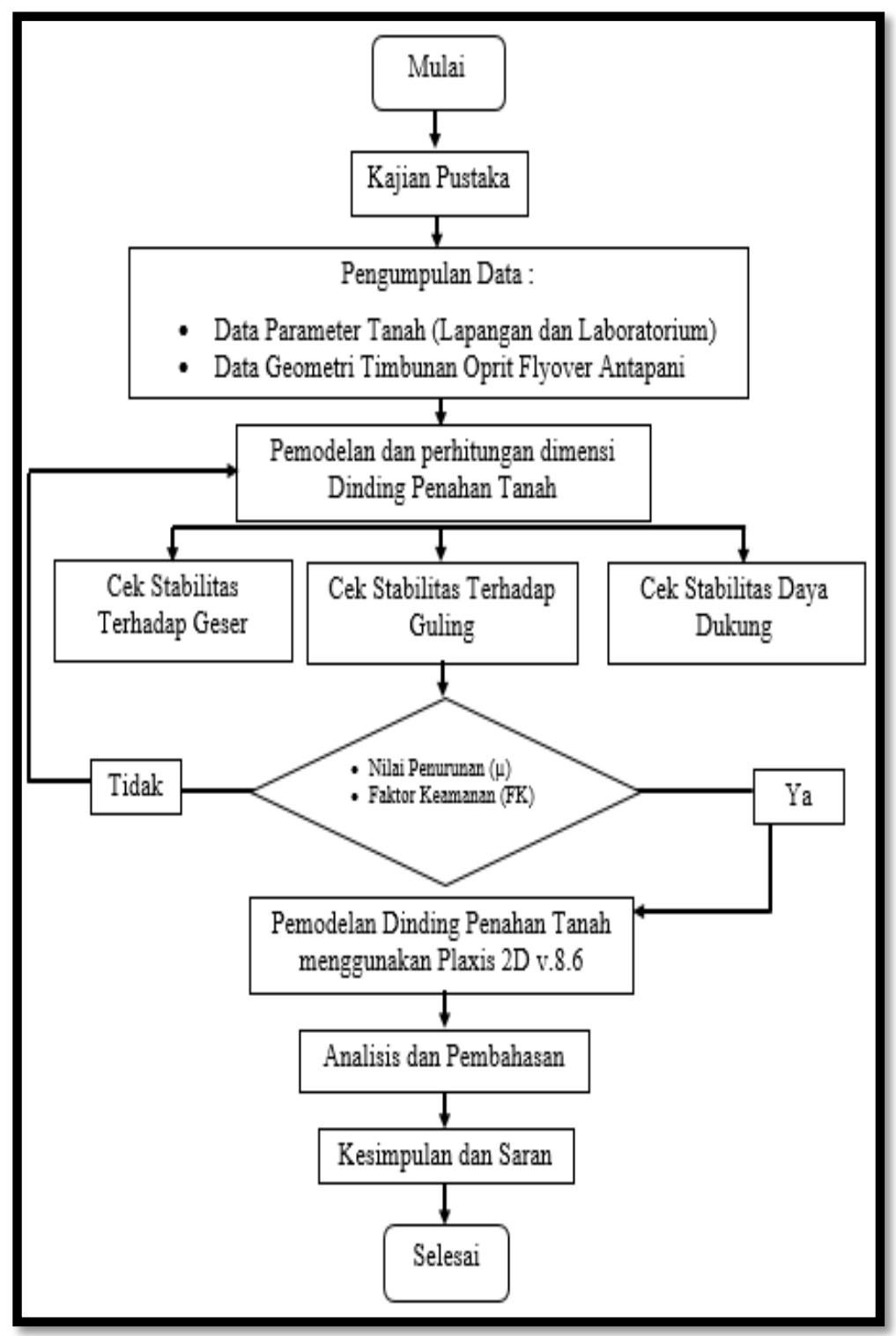

Gambar 10: Bagan Alir Penelitian

HASIL DAN PEMBAHASAN

\section{Perencanaan dan Pemodelan Dinding}

Penahan Tanah
Tahap ini merencanakan atau mengasumsikan perencanaan dinding penahan tanah pada flyover dengan memasukan geometri lapisan tanah yang sudah terkonsolidasi. 


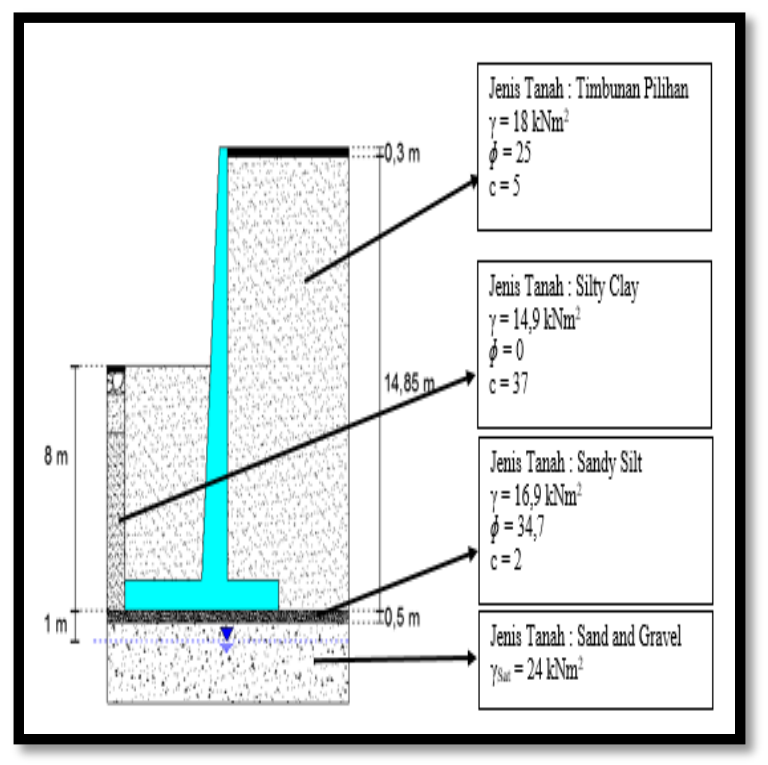

Gambar 11: Pemodelan Dimensi Dinding Penahan Tanah

\section{Cek Stabilitas Terhadap Gaya Geser} (Sliding)

Hasil cek stabilitas terhadap gaya geser pada pemodelan dinding penahan tanah adalah sebesar 1,86 dengan nilai faktor keamanan 1,5, maka dari itu cek stabilitas dinding penahan tanah terhadap gaya geser (Sliding) masih besar dari faktor keamanan minimum.

\section{Cek Stabilitas Terhadap Gaya Guling (Overturning)}

Hasil cek stabilitas terhadap gaya guling pada pemodelan dinding penahan tanah adalah sebesar 2,19 dengan nilai faktor keamanan 2, maka dari itu cek stabilitas dinding penahan tanah terhadap gaya guling (Overturning) masih besar dari faktor keamanan minimum.

\section{Cek Stabilitas Terhadap Daya Dukung}

\section{Tanah}

Hasil cek stabilitas terhadap daya dukung tanah pada pemodelan dinding penahan tanah adalah sebesar 10,48 dengan nilai faktor keamanan 3, maka dari itu cek stabilitas dinding penahan tanah terhadap daya dukung tanah (Bearing Capacity) masih besar dari faktor keamanan minimum.

\section{Pemodelan Dinding Penahan Tanah} Menggunakan Plaxis 2 Dimensi Versi 8.6

Analisis stabilitas dan penurunan oprit jembatan dilakukan dengan metode elemen hingga menggunakan perangkat lunak Plaxis Professional $2 D$ versi 8.6, dengan tujuan untuk membuktikan efektivitas penggunaan dinding penahan tanah dengan timbunan yang dapat mengurangi besarnya penurunan pada pemodelan dinding penahan tanah. Perancangan pemodelan geometri dinding penahan tanah. Pemodelan dilakukan dengan bantuan Plaxis Professional versi 8.6 yang dapat dilihat pada Gambar 12. 


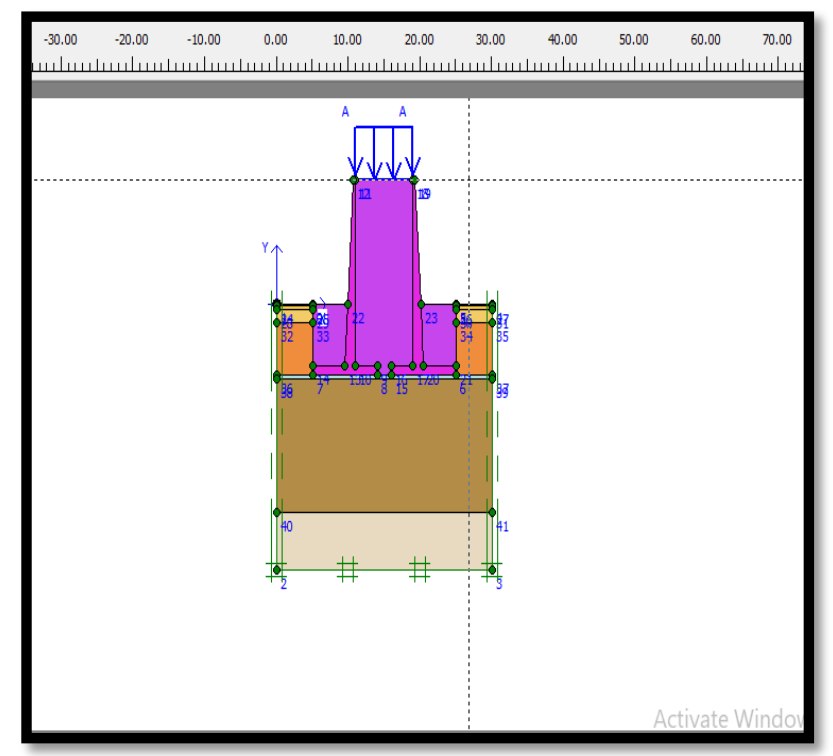

Gambar 12: Pemodelan dan Geometri Dinding Penahan Tanah

Hasil Output Analisis Pemodelan Dinding Penahan Tanah Menggunakan Plaxis 2 Dimensi Versi 8.6

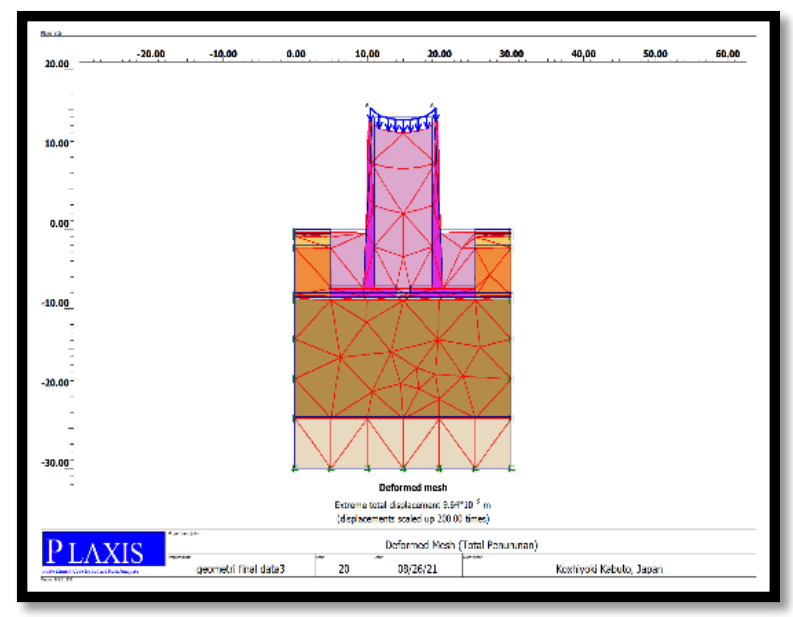

Gambar 13: Hasil Mesh Deformasi Dinding Penahan Tanah

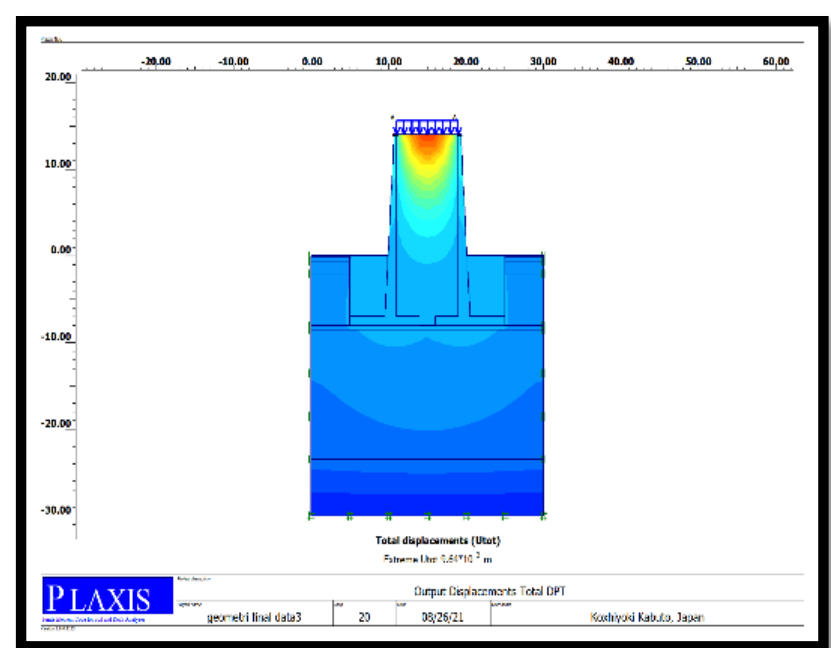

Gambar 14: Output Displacements Total 
Pada hasil analisis pemodelan dinding penahan tanah terlihat bahwa pemodelan dinding penahan tanah mengalami penurunan sebesar 0,96 cm dari hasil analisis didapatkan nilai safety faktor keamanan sebesar $10,9 \mathrm{~cm}$, adapun tampilan grafik pemodelan dinding penahan tanah ada pada Gambar 15 .

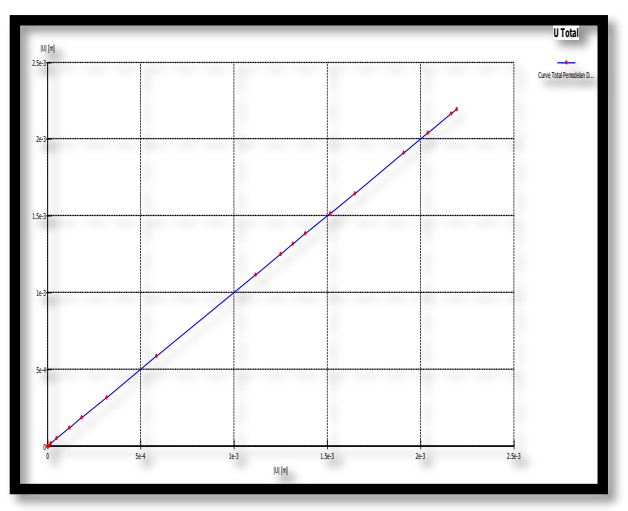

Gambar 15: Grafik Pemodelan Stabilitas Dinding Penahan Tanah

\section{KESIMPULAN DAN SARAN}

\section{Kesimpulan}

Dari hasil analisis pemodelan stabilitas dinding penahan tanah (DPT) dan penurunan antara dinding penahan tanah dengan timbunan, maka dapat disimpulkan sebagai berikut :

1. Berdasarkan hasil analisis pemodelan dinding penahan tanah (DPT) dengan perhitungan stabilitas terhadap geser dapat disimpulkan bahwa pemodelan dinding penahan tanah terhadap gaya geser aman terhadap penurunan dengan hasil perhitungan faktor keamanan 1, 86 $>1,5$.

2. Berdasarkan hasil analisis pemodelan dinding penahan tanah (DPT) dengan perhitungan stabilitas terhadap guling dapat disimpulkan bahwa pemodelan dinding penahan tanah terhadap gaya guling aman terhadap penurunan dengan hasil perhitungan faktor keamanan 2, 19 $>2$.
3. Berdasarkan hasil analisis pemodelan dinding penahan tanah (DPT) dengan perhitungan stabilitas terhadap kapasitas daya dukung (bearing capacity) dapat disimpulkan bahwa pemodelan dinding penahan tanah terhadap daya dukung (bearing capacity) aman terhadap penurunan dengan hasil perhitungan faktor keamanan 10, $48>3$.

4. Berdasarkan hasil analisis menggunakan Plaxis Professional versi 8.6 pada pemodelan dinding penahan tanah (DPT) mengalami penurunan sebesar 0,96 dengan faktor keamanan sebesar 12, 12, Maka dapat disimpulkan bahwa pemodelan dinding penahan tanah pada Flyover masih aman terhadap keruntuhan dikarenakan nilai penurunan masih kecil dari nilai faktor keamanan.

\section{Saran}

a) Dalam analisis, disarankan menganalisa dalam penentuan timbunan yang ada di 
pemodelan desain dinding penahan tanah pada proyek Flyover ini.

b) Melakukan pemodelan analisis dengan pemodelan 3 dimensi sehingga dapat dilakukan perbandingan.

c) Melakukan analisis dengan memasukkan faktor gempa pada pemodelan studi kasus dan dilanjutkan dengan penanganan kelongsoran.

d) Menghitung anggaran dan biaya untuk kebutuhan material pada perencanaan desain dinding penahan tanah.

\section{DAFTAR PUSTAKA}

[1] Siregar, C.A. (2017). Diktat dan Kuliah Mekanika Tanah I (Soil Mechanic I). Bandung: Fakultas Teknik Jurusan Teknik Sipil, Universitas Sangga Buana - YPKP.

[2] Rekayasa Fondasi I (Foundation Engineering I). Bandung: Fakultas Teknik Jurusan Teknik Sipil, Universitas Sangga Buana - YPKP.
[3] Siregar, C.A. (2017). Diktat dan Kuliah Rekayasa Fondasi II (Foundation Engineering II). Bandung: Fakultas Teknik Jurusan Teknik Sipil, Universitas Sangga Buana - YPKP.

[4] L.D. Wesley. 1988. Mekanika tanah. Jakarta: Badan Penerbit Pekerjaan Umum.

[5] Kementrian Pekerjaan Umum Direktorat Jenderal Bina Marga. 2010. Spesifikasi Umum Bina Marga 2010 Revisi 3, Devisi 3. Indonesia: Kementerian Pekerjaan Umum.

[6] Kementrian Pekerjaan Umum Direktorat Jenderal Bina Marga. 2010.Spesifikasi Umum Bina Marga 2010 Revisi 3, Devisi 3. Indonesia: Kementerian Pekerjaan Umum.

[7] Bowles, Joseph E. 1997. Analisis dan Desiain Pondasi Jilid 1. Jakarta: Erlangga.

[8] Braja M. Das. 1997. Advanced Soil Mechanics. California State University, Sacamento. 